\title{
Rock-lyriikoiden merkitys elokuvassa Veli
}

$\begin{array}{llllllllllll} & \mathrm{r} & \mathrm{a} & \mathrm{O} & \mathrm{s} & \mathrm{t} & \mathrm{e} & \mathrm{r} & \mathrm{b} & \mathrm{e} & \mathrm{r} & \mathrm{g}\end{array}$

Rock-musiikkia on käytetty ahkerasti angloamerikkalaisten elokuvien ääniraidoilla aina 1950-luvun nuorisokapinallisten kuvauksista lähtien. Venäjällä tämä kahden populaarikulttuurin keskeisimmän ilmiön synergia löydettiin hieman myöhemmin: vasta 1980-luvun lopulla perestroikan myötä. ${ }^{1}$ Kun lännessä oli jo siirrytty hyödyntämään rock-musiikin mukanaan tuomaa puhdistavaa voimaa toimintaelokuvien irrallisena taustamusiikkina sekä laskelmoituna kokoelmalevyjen ja oheismusiikkivideoiden markkinointina, Venäjällä 1990-luvun puoliväliin tultaessa rock-musiikki elokuvassa merkitsi edelleen realistisia konserttiesityksiä ja nuorisotematiikkaan liittyvää aihevalintaa.

Aleksei Balabanovin Veli (Brat, Venäjä 1997) oli yksi ensimmäisistä menestyselokuvista, jossa hyödynnettiin rock-musiikkia ilman, että elokuvan aihe ainakaan päältäpäin katsottuna käsitteli musiikin tekemistä tai nuorten kapinointia. Veli on toimintaelokuva, jossa nuori mies, Danila, saapuu maalta isoveljen luokse Pietariin ja ajautuu mukaan tämän välienselvittelyyn kaupungin alamaailman kanssa. Musiikin häpeilemätön käyttö kohtausten taustalla ilman tarinan tasolla motivoitua syytä koettiin kriitikoiden parissa väkinäisenä ja pinnallisena ratkaisuna
(Gladilššsikov 1997; Gladilšššikov 2000). Silti elokuvan musiikin käyttö poikkeaa suuresti myös kaupallisemmista amerikkalaisista kollegoista: elokuvan soundtrack koostuu pääosin vain yhden yhtyeen, Nautilus Pompiliusin musiikista. Tämän lisäksi yhtyettä ja sen musiikkia käsitellään toistuvasti myös elokuvan dialogissa ja se esiintyy muutamissa kohtauksissakin. Siten ehdoton raja realistisesti motivoidun (eli diegeettisen) ja vain taustalla soivan (ei-diegeettisen) musiikin välillä on hämärretty; realismin vaatimuksista ei täysin ole vielä luovuttu.

Veljen jatko-osassa, Brat-2:ssa (Venäjä, 2000) nähtiin jo toisenlainen, suoraviivaisempi lähestymistapa musiikkiin. Sillä oli kompilaatiosoundtrack, jota markkinoitiin kahtena cdlevynä, soitettiin ahkerasti Naše radiossa, ja hype huipentui mega-rock-konserttiin Moskovassa syyskuussa 2000. Jatko-osa noudatti selkeämmin läntisen genre-elokuvan ja markkinointistrategian kaavaa, ja siten tuntui vesittävän ja kääntävän nurin lähes kaiken, mitä ensimmäisessä oli niin tematiikan käsittelyn kuin musiikinkäytön saralla tehty.

Siksi onkin mielenkiintoista tarkastella, miten musiikki ja kuva yhtyvät juuri ensimmäisessä Veljessä. Mikä tekee sen musiikinkäytöstä ilmaisuvoimaisempaa ja rikkaampaa kuin sen jatkoosassa tai monissa vastaavissa amerikkalaisissa toimintatarinoissa? Osa vastauksesta piilee siinä, että sen voi nähdä eräänlaisena välimuotona matkalla venäläisestä elokuvamusiikkiperinteestä angloamerikkalaiseen kaupalliseen soundtrackiin. Sen musiikki on irronnut diegesiksestä, mutta ei ole täysin vielä sen ei-diegeettisellä puolella, vaan leijuu niiden välimaastossa. Toinen 
ratkaiseva tekijä liittyy elokuvassa käytettyjen laulujen lyyrikoiden integroitumiseen itse elokuvan tarinaan ja sen keskeisiin teemoihin, siitä huolimatta, että ne ovat aiemmin julkaistuja, jo olemassa olevia kappaleita. Tässä artikkelissa keskitytään tarkastelemaan tämän jälkimmäisen seikan merkitystä, ${ }^{2}$ toisin sanoen sitä, miten juuri lyriikat toimivat yhteistyössä kuvan kanssa; minkälaisia merkityksiä ne saavat elokuvan kontekstissa ja minkälaisia merkityksiä kuva saa, kun sen yllä leijuu jonkun ulkopuolisen ääni.

\section{Musiikki, sana ja kuva}

Yksi elokuvamusiikin tutkimuksen peruskäsitepareista on ajatus paralleelista ja kontrapunktista: musiikki joko myötäilee ja vahvistaa kuvan välittämää sanomaa tai on ristiriidassa sen kanssa. Tähän liittyy myös kysymys kuvan ja musiikin synkronisuudesta: musiikin tuottamisprosessi kuvauksen kohteena (esim. kuvamateriaali konsertista) olisi tällöin tavallaan nollatilanne, eräänlainen äärimmäinen paralleeli. Suuri osa elokuvamusiikin nykytutkijoista on jättänyt paralleelin ja kontrapunktin pohtimisen vähemmälle huomiolle tai pyrkii kyseenalaistamaan käsitteiden hyödyn pääosin siksi, että ne korostavat kuvan ensisijaisuutta musiikkiin nähden. Perimmäisenä ongelmana tässä ajattelussa on kuitenkin se, miten kahden eri aistin havainto ylipäänsä voi olla sama: milloin musiikin tai äänen sisältö on sama kuin kuvan ja milloin se on eri? ${ }^{3}$

Veli-elokuva alkaa näkymällä hailakankeltaisista syksyisistä puista ja järvestä, jota säestävät valssin tahtiin soittavat jouset. Kamera lähtee liukumaan vasemmalle, jossa näemme muuria vasten selin seisovan naisen, joka laskee mustan leninkinsä olkaimet. Samalla kun hän riisuu, kuuluvat laulun ensimmäiset sanat: "Sinä riisut iltapuvun, seisoen kasvot seinään päin"4. Näissä ensimmäisissä kuvissa musiikki ei ole synkronista, koska silloin tulisi näyttää orkesteria soittamassa, solistia laulamassa tai jokin muu äänen konkreettinen lähde. Voi kuitenkin ajatella, että soljuva valssin rytmi ja jouset muodostavat paralleelin liukuvalle kamera-ajolle ja luonnon- maisemalle. Musiikki tulkitaan lähtökohtaisesti ei-diegeettiseksi ja se vaipuu taka-alalle, sitä ei oikeastaan huomata laisinkaan (Gorbman 1987, 76-79).

Vasta lauletun tekstin asettuminen kuvan ja musiikin "päälle" pakottaa meidät kiinnittämään huomiota itse lauluun ja pohtimaan sen suhdetta esitettyihin kuviin. Tämä onkin katsottu yhdeksi rock- ja muun populaarimusiikin helmasynniksi elokuvissa: se kiinnittää liikaa huomiota itseensä ja siksi soveltuu heikosti elokuvamusiikin "perinteisiin" funktioihin. ${ }^{5}$ Tästä näkökulmasta laulut sopivat parhaiten erilliseksi musiikkinumeroksi, joka keskeyttää hetkeksi muun toiminnan, sillä sanat vievät aina katsojan huomion pois itse tapahtumista ja verbaalinen ilmaisu kaventaa mahdollisten merkitysten kirjoa (Gorbman 1987, 19-20; Brown 1994, 40). Veljen aloituskohtauksen ensimmäisten kuvien kohdalla tämä huomionhakuisuus ja merkityksen kaventuminen on viety äärimmilleen: laulun sanojen ("Sinä riisut") ja kuvan toiminnan (nainen riisuu) saumaton ykseys tavallaan kumoaa kummankin yksittäisen elementin merkityssisällön. Sen sijaan että yhdistelmästä syntyisi uusia merkityksiä, olemassa olevatkin nollautuvat ja jäljelle jää ainoastaan laulamisen ja naisen toiminnan korostunut performatiivisuus.

Toisenlainen ääripää syntyy myöhemmässä kohtauksessa, jossa kesken kidnappausoperaation Danila laittaa soimaan vauhdikkaan ja iloisen latinohenkisen Jamaika-kappaleen. Laulu on täysin epäsopiva jännittyneessä ja väkivaltaa uhkuvassa tilanteessa, eikä laulun teksti kaukokaipuusta tunnu liittyvän kohtaukseen mitenkään. Efekti on humoristinen. Mutta yhteensopimattomuus musiikin ja kuvan välillä on ainoastaan näennäinen, sillä katsojan pyrkimys on muodostaa aina mielekkäitä yhtäläisyyksiä näkemänsä ja kuulemansa välille (Gorbman 1987, 15). Musiikkivalinnan voi ajatella heijastelevan Danilan henkilökohtaista mielentilaa: ammattigangstereiden askeltaessa hermostuneina ympäri huonetta hän on tyyni ja huoleton, jopa kepeä. Laulussa ilmaistu toive olla jossain muualla voi henkilöityä myös kaapattuun 
mieheen, mitä assosiaatiota tämän merihenkinen raitapaita korostaa: laulu tuntuu pilkkaavan hänen ahdinkoaan.

Se seikka, että löydämme yhtäläisyyksiä musiikin ja kuvan välillä ei siis tee niistä kuitenkaan yksi yhteen sopivaa, sillä mielekkäitä yhtäläisyyksiä löytyy aina, oli ääniraidalla mitä tahansa. Toisaalta tietynasteinen asynkronia ja ristiriita ovat välttämättömiä uusien merkitysten syntymiselle. Aloituskohtauksessa laulettu "Sinä riisut" ja samalla näytetty riisuminen ei tunnu kovin mielekkäältä, mutta heti kun kamera siirtyy vahingossa kuvauspaikalle törmänneeseen Danilaan ja kuullaan seuraava lause: "Tahtoisin itkeä kivusta", merkitykset rikastuvat, sillä katsoja joutuu ponnistelemaan luodakseen yhteyden nähdyn ja kuullun välille.

Toinen musiikin ja laulun sanojen merkitykseen vaikuttava tekijä on sen suhde diegesikseen eli tarinan maailmaan. Claudia Gorbmanista (1987) lähtien elokuvamusiikkiteorian huomio onkin kiinnittynyt juuri diegeettisen ja ei-diegeettisen suhteeseen. Oikeastaan kyse on siitä, onko musiikki ylhäältä annettua, autoritäärisempää musiikkia, jonka tarkoitus on ohjata katsojan tunnereaktioita vai onko se henkilöhahmojen valitsemaa, kumpuaako se itse tarinasta. Yllä oleva esimerkki Jamaika-laulun käytöstä ei olisi yhtä hauska, jos kyse olisi pelkästään ohjaajan valinnasta. Silloin se olisi hämmentävä, osoitteleva, alleviivaava - kertakaikkisen huono vitsi. Laulut sanat voivat siis toimia ironisena kommentaarina, mutta ainoastaan diegeettisenä efekti on tehokas: sanat ikään kuin vahingossa sattuvat sopimaan tilanteeseen (Gorbman 1987, 23). On paradoksaalista, että katsoja mieltää tämän "luonnollisemmaksi" kuin ohjaajan tarkoituksella valitseman ei-diegeettisen kappaleen.

Vaikka ei-diegeettinen elokuvamusiikki, siis useimmiten taustamusiikki, onkin eräänlainen elokuvamusiikin perusmuoto, voidaan ajatella, että diegeettiselle tasolle mentäessä musiikin merkitykset itse asiassa rikastuvat. Ei-diegeettinen musiikki on ikään kuin suoraa ohjaajan elokuvaan koodaamaa lukuohjetta katsojalle, kun taas diegeettisen musiikin parissa katsoja joutuu vieläkin enemmän miettimään sanan ja musiikin suhdetta kerrottuun tarinaan ja sen hahmoihin. Kyseessä on eräänlaisen ehdollisen sattumanvaraisuuden illuusio. Osittain jännite syntyy siitä, että henkilöhahmot kuulevat saman laulun, mutta ainoastaan katsoja kykenee ymmärtämään sen "täydellisen" merkityksen. Toisin sanoen yksittäinen laulu tuo kerrontaan runsaasti merkityksiä riippumatta siitä, kuullaanko se diegeettisenä vai ei-diegeettisenä, mutta diegeettisellä variantilla on aina yksi merkitystaso enemmän.

\section{Nautilus ja Kormiltsevin sana}

Veli-elokuvassa kuullaan yhteensä kymmenen eri Nautilus Pompilius -yhtyeen kappaletta. Ne muodostavat elokuvan musiikkiraidan keskeisen sisällön; Nautiluksen musiikki on elokuvan musiikillinen idiomi, johon verrattuna kaikki muu on merkityksellistä poikkeusta. Lisäksi Nautiluksen kappaleet ovat ainoita, jotka kykenevät murtamaan diegesiksen rajat ja siirtymään korkeammalle, ei-diegeettiselle, "puhtaamman" elokuvamusiikin tasolle. Ja ainoastaan Nautiluksen kappaleiden lyriikat saavat korostettua huomiota osakseen: ne ovat hetkiä, jolloin dialogi väistyy ja yksittäisten tekstikatkelmien seuraaminen on katsojalle mahdollista. Tällaisina hetkinä sanoitusten sisältö nousee kerrontaa, tematiikkaa ja päähenkilöä kommentoivaksi metatekstiksi; toisin sanoen muuksikin kuin vain hetkellisen huumorin lähteeksi.

Yhtenä perestroika-ajan tunnetuimmista rock-yhtyeistä Nautilus Pompiliuksen näkyvä ja kuuluva esiintyminen Veljessä tuo venäläiselle katsojalle mukanaan voimakkaita assosiaatioita menneestä ajasta ja paikasta. Aikanaan kantaaottavat ja jopa kumoukselliset sanoitukset sitovat yhtyeen tiukasti 1980-1990-lukujen taitteeseen, heidän maineensa huippukauteen, sekä ensimmäisiin Neuvostoliiton romahtamisen jälkeisiin vuosiin, jolloin yhtyeen undergroundlevytykset julkaistiin ensimmäistä kertaa virallisesti. 1990-luvun jälkipuoliskolla kuitenkin kokoonpanoaan jo vaihtaneen ja pietarilaistuneen yhtyeen maine alkoi hiipua, kerran vaihtoehtoa 
ja maanalaista ääntä edustanut oli muuttunut etabloituneeksi valtavirraksi ja sanoitukset poliittisista filosofis-lyyrisiksi. Vuonna 1997 yhtye lopetti virallisesti toimintansa.

Nautiluksen nostaminen esiin Veli-elokuvassa eräänlaisena joutsenlauluna ei ollut sattumaa. Ohjaaja Aleksei Balabanov oli tutustunut yhtyeen keulahahmoon Vjatšeslav Butusoviin jo 1980-luvun alun Sverdlovskissa ja hänen esikoisohjauksensa, Ranše bylo drugoje vremja (Ennen oli toinen aika, 1985) on oikeastaan kappaleen "Vzgljad s ekrana" (Katse valkokankaalta) musiikkivideo. Nautilus oli siten luonnollinen valinta Veljen musiikkiraidan kantavaksi voimaksi. Ja olivat Nautiluksen musiikkia muutkin elokuvissaan käyttäneet: toinen sverdlovskilainen ohjaaja Vladimir Hotinenko hyödynsi kappaletta "Prošalnoje pismo" (Jäḧhyväiskirje) scifi-elokuvassaan Sankarin kuvastin (Zerkalo dlja geroja, 1987). Kyseessä oli ajalle tyypillinen konserttikohtaus, jonka funktiona on sitoa elokuvan aloitus ajan henkeen ja sukupolvien väliseen problematiikkaan.

Mutta se, että Veljessä yhtye oli niin näkyvästi läsnä ilman tarinan aiheesta kumpuavaa motiivia, ei ollut kriitikoista pelkästään myönteinen asia. Se oli pelkkä uusimman albumin mainos (Gladilšstsikov 1997) tai suorastaan anakronismi: yhtye edustaa täysin eri sukupolvea kuin päähenkilö (Mantsov 1998). Jälkimmäiseen seikkaan liittyen monet kiinnittivät huomiota siihen, että kantaaottavana pidetyn yhtyeen tekstit eivät tunnu tekevän minkäänlaista vaikutusta nuoreen Danilaan, hän kuuntelee, muttei kuule sanoja (Margolit 1998, Gladilšššikov 2000). "Hlop-hlop" (Pam pam) on selkein esimerkki tästä: sodasta palannut Danila hurraa konsertissa muun yleisön mukana, kun Butusov laulaa nuorista miehistä, jotka tykinruoaksi kasvatetaan. Huomiotta jäi se seikka, että Nautiluksen uran alkupään poliittisempia hittejä ei elokuvassa kovin montaa kuulla; soundtrackin pääpaino on tuoreemmalla, lyyrisemmällä musiikilla.

Suurin osa Veljessä kuultavista teksteistä, aivan kuten suurin osa Nautiluksen laulujen teksteistä ylipäänsä, on lähtöisin runoilija Ilja
Valerjevitš Kormiltsevin (1959-2007) kynästä. Ne muodostavat elokuvan keskeisen lyyrisen kuvaston, jota muutamat Butusovin laatimat tekstit (mm. "Hlop-hlop") myötäilevät ja tukevat. Kormiltsevin lauluille tyypillistä on urbaani dekadenssi ja romanttinen toivottomuus; rakkaus, kärsimys ja tuho. Yhtenä toistuvana motiivina on rakastetun naisen kuolema, yleensä putoamalla tai syöksymällä. Mielikuvaa vahvistaa myös toistuva ilmaan nousemisen ja lentämisen symboliikka toivon vertauskuvana. Vaikka yhtäkään Veljen musiikkiraidalla käytetyistä lauluista ei ole kirjoitettu elokuvaa varten, yhden tekijän tekstit muodostavat kuitenkin temaattisesti eheän ja tiiviin kokonaisuuden. Lisäksi sanoitusten muoto on useimmiten sopivan avoin, kuten populaarimusiikissa yleensäkin, joten tekstien merkitys taipuu helposti moniin eri konteksteihin ja monenlaisiin tulkintoihin.

Elokuvamusiikkina rock-laulut ovat selkeästi erottuvan, itsenäisen rakenteen omaava elementti, teos teoksen sisällä. Silti, huomionhakuisuudestaan huolimatta, niiden läsnäolo ei estä katsojaa seuraamasta sitä, mitä tapahtuu, vaan ne tuovat uusia merkityksiä siihen, ehkä jopa tavallaan verbaalisella tasolla korjaavat rokkibiitin kykenemättömyyden "eläytyä" tapahtumiin syvemmin. Katsojan huomion kiinnittyminen musiikkiin on kuitenkin täysin manipuloitavissa, joko volyymia tai muun kerronnan intensiteettiä vaihtelemalla. Huomio ohjautuu siten kuvan seuraamisesta sanojen kuunteluun ja takaisin, suurimmaksi osaksi tekijän tahdon mukaisesti. Tästä seuraa, että teksti, jo itsessään vain laulufragmentti, fragmentoituu entisestään pienemmiksi yksiköiksi, jotka muodostavat tiiviimmän kokonaisuuden samanaikaisesti nähtävän kuvan kanssa, kuin mitä edeltävien ja seuraavien tekstifragmenttien kanssa. Sanoitusten lineaarisen narratiivisuuden painoarvo vähenee ja yksittäisten lauseiden merkitys korostuu. Tämä ei kuitenkaan merkitse sitä, etteikö laulujen sisällöllä kokonaisuutena olisi mitään merkitystä. Merkityksen synnyssä on ikään kuin kaksi tasoa: on laajempi kerronnan kaari ja sen ohella yksittäiset, hetkellisesti muodostuvat merkitykset. ${ }^{7}$ 


\section{Liukuva subjekti}

Katsoja pyrkii suhteuttamaan laulettujen sanojen merkitystä suhteessa kuvaan ja hakemaan selitystä niiden läsnäololle. Tämä koskee erityisesti synkronoimatonta ääntä: hetkiä, jolloin äänen lähde ja diegeettisyyden aste on epävarma tai häivytetään katsojan tietoisuudesta. Kun Danilan astuessa kuvaan samaan aikaan kuuluu ääni, joka laulaa "Tahtoisin itkeä kivusta", nousee väistämättä esiin kysymys, kuka se oikeastaan on, joka näin sanoo. Kuka on tuo "minä", joka tahtoo itkeä? Toisin sanoen, mikä on kuvan ulkoisen, ei-synkronisen lauluäänen positio suhteessa elokuvan maailmaan?

Kohtauksessa, jossa Danila tappokeikalle valmistautuessaan rakentaa asetta, kuulemme äänen laulavan "Tässä likaisessa maassa / voit tulla suureksi / voit tuhoutua", sekä näemme lähikuvan Danilan kasvoista ja ääni laulaa "kuin viaton lapsi”, sitten seuraa lähikuva käsistä rakentamassa asetta ja ääni laulaa "kuin hellä vampyyri"”. Äänen on helppo ajatella kuvailevan suoraan elokuvan suurkaupunkitematiikkaa, päähenkilön edessä olevaa tehtävää sekä tämän kaksijakoista luonnetta. Lähtökohtaisesti ääni, jonka lähdettä ei nähdä, koetaan autoritärisempänä kuin näkyvään fyysiseen subjektiin yhdistyvä ääni (Lotman \& Tsivjan 1994, 145). Siten ei-synkroninen lauluteksti helposti mielletään tarinalle ulkopuolisena, eräänlaisen kaikkitietävän tekijän kommentaarina.

Mutta jos "Nežnyi vampir"(Hellä vampyyri) -laulun kuuntelee kokonaan, siinä itse asiassa laulun lyyrinen minä kuvailee itse itseään vampyyrina. Silti ajatus tekstistä Danilan sisäisenä puheena ei tunnu uskottavalta. Kuten aiemmin todettiin, useimmat venäläiset kriitikot kokevat, että Danila ei kuuntele eikä ymmärrä laulettuja sanoja, Danilan puhe tai käytös ei millään tavoin viesti kyvystä havainnoida tai pohdiskella analyyttisesti ympäristöään. Lyyrisen minän sijaan Danila useimmiten assosioituukin laulutekstien "sinäksi" ja siten sekä laulamisen että kuvaamisen kohteeksi, objektiksi eikä subjektiksi, kun taas laulun "minä" assosioituu kuvan ulkopuoliseen tekijään ja tekijyyteen. Danila on elokuvan päähenkilönä korostetusti objekti, tekijänsä luomus, mihin osa lauluteksteistä myös suoraan viittaa. ${ }^{9}$

Kaiken lisäksi Nautiluksen lauluissa "sinä" on useimmiten nainen, miespuolisen lyyrisen minän onnettoman rakkauden kohde. Elokuvan kontekstissa miehen ja naisen suhdetta kuvaileva teksti muuttuu tekijän (ohjaaja Balabanovin) ja hänen fiktiivisen päähenkilönsä (Danilan) suhteen metakommentaariksi. Siten laulujen sanojen kautta tapahtuu päähenkilön feminisaatio ja objektivisointi: hän ei olekaan aktiivinen subjekti vaan naishahmojen tavoin valkokankaan "maskuliinisen katseen" ja laulamisen kohde.

Kaiken kaikkiaan persoonapronominien kohteiden irtautuminen laulun alkuperäisestä kontekstista on ehkä selkein esimerkki siitä, miten laulun oma koherenssi antaa myöten kuvan ja sanan luomien uusien assosiaatioiden tieltä. Mutta subjektius ei pelkästään irtaannu alkuperäisestä kontekstistaan ja yhdisty johonkin tiettyyn uuteen kohteeseen elokuvassa, vaan se liikkuu ja liukuu, vaihtaa assosiaatiokohdettaan, riippuen täysin siitä, mitä milläkin hetkellä kuvassa näemme. Se, mikä yhtenäisen lauluntekstin kontekstissa on yhtenäinen minä, pirstaloituukin useiksi eri subjekteiksi. Tästä näkökulmasta aiemmin käsitelty aloituskohtaus on mahdollista lukea monella tapaa. "Krylja" (Siivet) -laulun sanat ja otosten kuvallinen sisältö rinnastuvat seuraavalla tavalla:

\begin{tabular}{|c|c|}
\hline Laulun sanat ${ }^{10}$ : & Otoksien sisältö: \\
\hline Sinä riisut iltapuvun & $\begin{array}{l}\text { Vaalea nainen seisoo } \\
\text { selin, kasvot kivimuu- } \\
\text { ria päin, riisuu mekon } \\
\text { ja paljastaa selkänsä. }\end{array}$ \\
\hline $\begin{array}{l}\text { Seisoen kasvot sei- } \\
\text { nään päin } \\
\text { Minä näen tuoreet }\end{array}$ & $\begin{array}{l}\text { Yleiskuva kuvaus- } \\
\text { ryhmästä, keskellä } \\
\text { valtava kamerakraana }\end{array}$ \\
\hline
\end{tabular}




\begin{tabular}{|l|l|}
\hline haavat sametinpeh- & Danila kapuaa ku- \\
meässä selässä & vaan, katse suunnattu- \\
Minä tahtoisin itkeä & na kuvan ulkopuolelle \\
kivusta & (äskeisen kuvan kuva- \\
tai unohtautua & usryhmään) \\
\hline uneen, missä ovat si- & Yleiskuva kuvausryh- \\
nun siipesi, jotka & mästä \\
\hline niin miellyttivät mi- & Ohjaaja istuu nyrpeä \\
nua & ilme kasvoillaan \\
\hline
\end{tabular}

Aloituskuvan "sinä" on nainen, joka on kääntynyt selin; hän on korostetun passiivinen sanallisen ja visuaalisen kuvauksen kohde. Toinen otos paljastaa edellisen kuvan subjektin, eli kuvausryhmän ja valtavankokoisen kamerakraanan yhdistettynä säkeeseen: "minä näen". Kolmannessa kuvassa näemme Danilan, joka rinnastuu aloituskuvan naiseen sekä sijaintinsa puolesta (hän nousee sieltä mistä aloituskuvan kamera-ajo alkoi) että leikkauksen tasolla (otos on oppositiossa kuvausryhmäkuvaan). Naista ja Danilaa erottaa kuitenkin passiivisuuden aste: nainen ei itse katso ketään ja häneen liittyy "sinuus", Danila puolestaan katsoo takaisin kuvausryhmään ja hänen yhdistyy "minuus". Jos ajatellaan, että Danila todella nousee lyyriseksi subjektiksi tässä otoksessa, voidaan tulkita, että hän on se, joka tahtoo itkeä ja joka kysyy kuvausryhmältä heidän siivistään. Toisin sanoen nuori, potentiaalinen katsoja kysyy taiteen tekijöiltä, mihin on kadonnut heidän kykynsä luoda unelmia. Toisaalta, jos ajatellaan, että lyyrinen minuus lukittuu elokuvantekijöiden puolelle, silloin "Minä tahtoisin itkeä" on tekijän kommentti tulevasta päähenkilöstään: sodan traumatisoiman nuoren Danilan näkeminen saa ohjaajan itkemään. Tähän tulkintaan viittaa myös "niin miellyttivät minua" -fragmentin yhdistyminen fiktiivisen ohjaajan nyrpeään naamaan peräti kahdesti kohtauksen aikana: hän on se, jonka mieltymyksistä kaikessa on viime kädessä kyse.

Kuitenkin myös laulujen todellinen "minä", eli laulusolisti Butusov, esitellään myöhemmin elokuvassa katsojalle. Vaikka katsoja toden- näköisesti alusta asti tietää, että kyseessä on Butusovin ääni, niin kauan kuin hän pysyy kameran takana, pelkkänä autoritäärisenä äänenä kuvien yllä, hän kuuluu samaan kategoriaan tekijän kanssa: hän ja Balabanov edustavat yhtä, yhtenäistä positiota. Mutta mielenkiintoista on se, että jopa kohtauksissa, joissa Butusov on itse läsnä ja laulaa, tekstin minuus yhdistyy häneen vain niin kauan kuin kuva on hänessä, siis synkroninen. Heti kun leikataan muualle, alkaa subjektius leijua ja hakea sopivaa assosioitumiskohdettaan: näin tapahtuu esimerkiksi "Hlop-hlop"-kappaleen aikana.

Se, että laulujen lyyrinen subjektius on todellisuudessakin jakautunut kahtia Butusovin ja Kormiltsevin persooniin, heijastuu siinä, ettei Butusovia kertaakaan näytetä laulamassa Kormiltsevin tekstejä: kumpikin konserttitaltiointi esittää hänet laulamassa itse tekstittämiään kappaleita. Tällainen lyyrisen minän lähtökohtainen monistuminen on elokuvassa arkipäivää: auteur-tulkinnoista huolimatta elokuva on aina kollektiivin tuotos. Toisaalta myös päähenkilö usein muuttuu koko elokuvan näkökulman subjektiksi, vaikka tekstin on laatinut ohjaajakäsikirjoittaja. Hienovaraisilla subjektipositioilla ei useimmiten ole taiteen kuluttajalle mitään merkitystä. Tämä heijastuu myös Danilan suhtautumisessa fanittamaansa musiikkiin: hän itse kertoo menevänsä konserttiin, jossa "Nautilus laulaa". Silti aloituskohtauksessa hän on se, joka kiinnittää huomion ohjaajan ja näyttelijän sijaan juuri laulajaan, ääneen kuvien yllä, ja verbalisoi katsojien huulilla olevan kysymyksen: "Mikä laulu tämä on?" Se, että henkilöhahmokin huomaa huomaamattomaksi tarkoitetun kappaleen, rikkoo alun elokuvallisen illuusion lopullisesti. Se toimii metakommenttina elokuvamusiikin perinteiseen käyttöön ja rock-kappaleiden ominaispiirteisiin: niitä yksinkertaisesti ei voi olla huomaamatta.

\section{Musiikin pelastava rooli}

Elokuvan diegeettinen musiikki, eli Nautiluksen kappaleet, joita Danila oletettavasti kannettavalla 
soittimellaan kuuntelee, saa tärkeän symbolisen merkityksen elokuvan edetessä. Tutkijat ovat yhtä mieltä siitä, että aloituskohtauksessa kuultava kappale "Krylja" symboloi siipiä, joiden avulla Danila pyrkii nousemaan väkivaltaisen arjen yläpuolelle (Beumers 1999, 85; Larsen 2003, 506). Nautiluksen musiikkiin kiteytyy Danilan vaiettu toive paremmasta elämästä, pois väkivallan piiristä. Kannettavan soittimen kuulokkeet muodostavat musiikin täyttämän kuplan, jonka läpi on helpompi toimia maailmassa. Päähenkilö selvästi pakenee ja sulkee itsensä musiikkiin, ja soitin lopulta jopa konkreettisesti pelastaa hänen henkensä. Tämä musiikin saama rooli elokuvan tematiikassa artikuloituu myös laulujen sanoituksissa.

"Krylja" on kaikista elokuvan lauluista ainoa, joka saa nimen, ja sellaisena se nousee edustamaan kaikkia Nautiluksen lauluja ja musiikkia ylipäänsä, se on laulujen laulu. Se on elokuvan johtoaihe, mutta ei kirjaimellisessa musiikillisessa mielessä, vaan temaattisesti. Sillä vaikka se aloittaa koko elokuvan ja on siten musiikkiraidan tärkeimmällä paikalla, kappaletta ei kuulla kuin puoliväliin, minkä jälkeen ohjaaja katkaisee sen kesken, eikä laulua enää kuulla koko elokuvan aikana. Sen sijaan aloituskappaleen käynnistämä lentämisen ja ilmaan nousemisen motiivi toistuu muissakin elokuvassa esiintyvistä sanoituksista.

Tärkeä vastakappale "Kryljalle" on "Ljudi na holme" (Ihmiset kukkulalla), joka siivittää Danilan saapumista Pietariin ja näin käynnistää elokuvan varsinaisen tapahtumaketjun provinssiin sijoittuvan prologin jälkeen. "Ljudi na holme" on synkkä, hidas, konetaustainen kappale, jonka lyriikat eivät enää sisällä pätkääkään toivoa - jos siis ajatellaan, että "Kryljassa" lausuttu ajatus siitä, että edes joskus on ollut siivet, edustaa pientä toivon kipinää. Yhdistettynä Pietarin eri puolia esittelevään montaasiin "Ljudi na holmessa" kiteytyy elokuvan suurkaupunkimotiivi: gangstereiden valtaamassa kaupungissa ihmisen elämä pelkistyy järjettömäksi valtataisteluksi, jolta välttyy ainoastaan hyppäämällä kokonaan kyydistä pois. Siten lentämisen sijaan ainoa realistinen aseman muutos on alas syöksymi- nen. Laulun merkitys suhteessa keskeytettyyn "Kryljaan" korostuu siinä, että se kuullaan lähestulkoon kokonaisuudessaan ja peräti kahdesti elokuvan aikana: se soi myös elokuvan lopetuksessa, jolloin kyseessä on tosin kappaleen nopeatempoisempi demo-versio, mikä korostaa loppuratkaisun odottamatonta ja jopa kiusallista kepeyttä.

Näiden kahden laulun, "Kryljan" ja "Ljudi na holmen", vastakkaisuus heijastelee koko elokuvan keskeistä temaattista vastakkainasettelua: toisaalta on ilmaan nouseminen ja siivet toivon ja pelastuksen motiivina, jota edustaa ajatus musiikista ylipäänsä pelastavana voimana, ja toisaalta taas sen vastakohta, alas syöksyminen ja kuolema, joita edustaa gangstereiden maailman väkivaltaisuus - ja musiikin puuttuminen. Näiden kahden maailman, fantastisen musiikin maailman ja väkivaltaisen reaalimaailman ero havainnollistuu jo mainitussa kohtauksessa, jossa Danila rakentaa aseen "Nežnyi vampir" -kappaleen tahdissa. Kohtaus alkaa Nautilusjulisteen lähikuvasta, jonka jälkeen kamera tarkentuu kuvan etualalla olevaan korvaan, jossa on kuulokenappi, sitten kamera tilttaa eli kääntyy alas ja paljastaa luodinreikiä peilin pinnassa, mikä osoittaa Nautiluksen kuvan ja korvan olleen pelkkiä heijastuksia. Liike jatkuu alas, ohi peilin, ja kohtaa pöydällä cd-soittimen, sitten pistoolin ja lopuksi kuvaan tulevat Danilan kädet. Näin ollen peilipinta jakaa maailman kahtia: toiselle, heijastuksen puolelle kuuluvat Nautilus, musiikki ja Danilan korva (pää, ajatukset), ja toiselle puolelle, reaalimaailman puolelle, kuuluvat ase ja kädet muusta kehosta erotettuna pommia rakentamassa. Rakentamisen edetessä ääni laulaa: "Tiedät kyllä miksi ilmestyin luoksesi / antamaan sinulle voiman / antamaan sinulle vallan"11. Tilttauksen, montaasin ja laulun yhdistelmällä kiteytetään musiikin merkitys päähenkilölle ja koko elokuvalle: musiikki antaa nuorelle ihmiselle voimaa kestää arki auttamalla irrottautumaan siitä; kohottamalla ajatukset pois siitä, mitä käsien täytyy tehdä. ${ }^{12}$

Musiikillisten siipien ja musiikittoman väkivallan ristiriita päähenkilön elämässä huipentuu 
"Tšornyje ptitsy" (Mustat linnut) -kappaleessa ja montaasissa, jossa Danila valmistautuu loppukonfrontaatioon. Jos "Krylja" ja Nautiluksen musiikki ja sitä kautta lentämisen motiivi ovat tähän asti Danilan elämässä edustaneet hyvää, toivottua asiaa, niin nyt kuullaan hurjalla intensiteetillä alusta loppuun kuvaus siitä, miten ylhäältä kuusta lentää alas mustia lintuja silmiä nokkimaan ja tekemään pahaa. Lähikuva Danilan kasvoista yhdistyy lauseeseen: "Mustat linnut lasten silmistä / mustalla nokalla timantteja nokkivat"13. Danila rinnastuu lapseen ja mustiin lintuihin symbolina yhdistyy ajatus kaikesta siitä pahasta mitä hän on elämänsä aikana, sodassa ja sen ulkopuolella nähnyt ja kokenut; toisaalta linnut edustavat sitä välitöntä uhkaa, jonka gangsterit muodostavat ja johon on pakko reagoida.

Mutta miten nyt tulee tulkita "minä" ja "sinä" laulussa, joka omassa kontekstissaan on kansansatuun pohjautuva dialogi mustien lintujen ja kuninkaan välisistä huonosti päättyvistä neuvotteluista? Kokonaiset säkeistöt saavat seurakseen erikoislähikuvia Danilan käsistä, työn eri vaiheista, yhdistyen tekstiin, jossa laulun kuningas vuoronperään tarjoaa linnuille eri lahjuksia ja linnut yksi kerrallaan hylkäävät ne: "emme tarvitse kultaasi / valtakuntaasi / puusta tehtyä kruunuasi"14. Voi ajatella kuninkaan tarjouksen ja sen saaman tyrmäävän vastauksen rinnastuvan valheellisen veljen houkutteluihin, joista Danila kieltäytyy nousemalla sekä gangstereita, että veljeään vastaan. Erityisesti korostuu laulun viimeinen säkeistö:

\begin{tabular}{|l|l|}
\hline Laulun sanat $^{15}:$ & Otoksien sisältö: \\
\hline Ottakaa sitten silmäni & Danila istuu sängyllä, \\
Ottakaa sitten silmäni & puhdistaa haulikkoa, \\
Ottakaa sitten silmäni & katsoo piippuun \\
\hline Jottei teitä enää ikinä & Lähikuva jaloista, \\
näkisi & solmii kengännauhat \\
Emme enää tarvitse & \\
silmiäsi & \\
\hline
\end{tabular}

\begin{tabular}{|c|c|}
\hline \multirow[t]{2}{*}{$\begin{array}{l}\text { Emme enää tarvitse } \\
\text { silmiäsi } \\
\text { Me olimme jo kerran } \\
\text { silmissäsi } \\
\text { Ja kaiken tarpeellisen } \\
\text { sieltä veimme }\end{array}$} & $\begin{array}{l}\text { Lähikuva käsistä, pat- } \\
\text { ruunat piippuun, } \\
\text { nousee sängyltä, } \\
\text { jättää aseen sängylle } \\
\text { levyjen viereen }\end{array}$ \\
\hline & $\begin{array}{l}\text { Peilikuva, Danila kat- } \\
\text { soo itseään silmiin }\end{array}$ \\
\hline
\end{tabular}

Kohtauksen voi jälleen lukea monella tapaa. Danila assosioituu dualistisesti sekä tarjoajaan että kieltäytyjään. Tämän voi siten tulkita sisäiseksi dialogiksi, joka heijastelee kahtia jakautunutta persoonaa. Vuoropuhelun voi edelleen nähdä jatkeena myös isoveljen ja pikkuveljen valtataistelulle, jossa Danila saa lopullisen yliotteen. Toisaalta kyseessä voi olla myös viite aikaisempaan aseenrakennusmontaasiin ja $\mathrm{Bu}$ tusovin lausumaan tarjoukseen kuulijalle: "Tulin antamaan voiman". Ja tästä tarjouksesta Danila nyt kieltäytyy, siivistä ei ole enää pelastajiksi, Danila valitsee väkivallan ja jättää musiikin. Mutta jos lähtee ensimmäisen assosiaation mukaisesti lukemaan Danilaa lintujen uhrina, jolta silmät on nokittu, ja sisältä viety kaikki, nousee kysymys, ketä linnut sitten edustavat? Onko se tekijä, joka on luonut omia tarkoitusperiään varten päähenkilön, jonka näkökulmasta hän nyt erkanee, vai yhteisö, joka on pakottanut lapsensa rintamalle ja sitten siviilissä jättää oman onnensa nojaan? Joka tapauksessa lauluosuus loppuu ja viimeinen lause, "kaiken tarpeellisen veimme", jää leijumaan ilmaan. Kohtauksen viimeisessä kuvassa Danila katsoo itseään peiliin; yleensä elokuvissa se merkitsee identiteetin hahmottamista ja oman äänen löytämistä. Kuvan yllä leijuu laulutekstin lopun implikoima tyhjyys, Danila on yksin itsensä kanssa, Butusovin (tekijän) ääni väistyy, ja koittaa sanaton, vain musiikin keinoin ilmaistava hetki.

Vaikka rock elokuvamusiikkina kiinnittääkin paljon huomiota itseensä ja on musiikilliselta ilmaisukyvyltään "köyhempää" kuin elokuvaan varta vasten sävelletty instrumentaali taidemusiikki, laulut kykenevät kuitenkin joustamaan, 
antamaan myös kerronnalle tilaa ja muodostamaan uusia merkityksiä omalla erityisellä tavallaan. Rock-lyriikat osallistuvat elokuvan merkityksen luontiin käsittelemillään teemoilla, mutta myös siten, että tekstin oma koherenssi pirstaloituu ja yksittäiset fragmentit muodostavat voimakkaita yhdistelmiä kuvallisen materiaalin kanssa.

Veljessä käytetyt Kormiltsevin tekstit tukevat tarinaa ja sen käsittelyä poikkeuksellisen vahvasti. Danilan kahtiajakautunut henkilöhahmo, suurkaupungin perimmäinen olemus sekä eloku- van peruskonfliktit saavat kaikki artikulaationsa sanoitusten kautta. Samalla laulettu sana on voimakas itseään kommentoiva elementti,johon sisältyy tekijyyden ja tekijän roolin pohdintaa. Elokuvassa on mielenkiintoisella tavalla taivutettu yhden yhtyeen ennalta olemassa olevaa musiikkia sopimaan kerrontaan, tuomaan siihen koherenssia ja sisältöä. Vaikka rock-musiikkia oli venäläisessä elokuvassa käytetty jo 1980-luvun lopulta alkaen, Veli legitimoi lopullisesti venäläisen populaarimusiikin "oikeaksi" elokuvamusiikiksi muiden musiikkilajien rinnalle.

Viitteet

1 Silloin syntyi eräänlainen nuorisoelokuvan alalaji, perestroika-rock-elokuva, jonka ytimen muodostavat Sergei Solovjovin trilogia: Assa (1987), Tšornaja roza-emblema petšali, krasnaja roza - emblema ljubvi (Musta ruusu on surun tunnus, punainen ruusu on rakkauden tunnus, 1989) ja Dom pod zvjozdnym nebom (Talo tähtitaivaan alla, 1991), sekä mm. Valeri Ogorodnikovin Murto yössä (Vzlomštšik, 1986) ja Rašid Nugmanovin Piikki (Igla, 1988).

2 Veljen musiikista diegeettisen ja ei-diegeettisen eron näkökulmasta, ks. Österberg 2010.

3 Paralleelin ja kontrapunktin kritiikistä ks. esim. Gorbman 1987, 15; Mera 2005: 92. Suurimman vaivan on nähnyt Lexmann (2006, 116-118), joka on pyrkinyt laajentamaan käsiteparia lukuisilla alakategorioilla, ilman että perusongelma häviää mihinkään.

4 Ks. loppuviite 10.

5 Suurin osa elokuvamusiikin teorianmuodostusta käsittelevistä monografioista (esim. Gorbman 1987, Brown 1994, Lexmann 2006) keskittyy tutkimaan pääasiassa instrumentaalimusiikkia painottavia elokuvia. Näistä lähtökohdista on kuitenkin onnistuneesti tutkittu myös populaarimusiikin roolia elokuvissa, esimerkkinä Mera 2005. Rock- ja populaarikappaleiden lainalaisuuksia elokuvamusiikkina on onnistuneesti taidekeinona hyödynnetty aina 1960-luvulta lähtien kansainvälisessä auteur-perinteessä, ks. Gorbman 2007. Tällöin musiikkivalikoima

(muiden taidekeinojen ohella) tuo mukanaan korostuneesti juuri tekijän läsnäolon. Gorbman listaa tähän genreen kuuluviksi ohjaajiksi mm. Godardin, Kubrickin, Scorsesen, Tarantinon ja Kaurismäen. Listan jatkoksi sopisi luonnollisesti hyvin myös Balabanov.

6 Ks. loppuviite 10.

7 Lexmann kutsuu musiikin ja kuvan vuorovaikutusta "vertikaaliseksi audiovisuaaliseksi montaasiksi", jolla on kaksi eri tasoa: hetkellisesti havaittava ja laajemman elokuvallisen toiminnan taso $(2006,114)$.

8 "V etoi strane vjazkoi kak grjaz / Ty možeš stat tolstoi / Ty možeš propast / [---] / Kak nevinnyi rebjonok / kak nežnyi vampir"

9 Esimerkiksi "Vo vremja doždja" (Sateella) -kappaleessa: "Minä keksin sinut keksin sinut / sateella kun ei ollut muutakaan tekemistä / [---] / Mitä minä teen kanssasi? / Mitä me teemme nyt?" ("Ja pridumal tebja pridumal tebja / ot netšego delat vo vremja doždja / [---] / Što mne delat s toboi? / Što nam delat teper?")

10 "Ty snimaješ vetšerneje platje, stoja litsom $\mathrm{k}$ stene / I ja vižu svežije šramy na gladkoi, kak barhat spine / Mne hotšetsja plakat ot boli ili zabitsja vo sne / Gde tvoi krylja kotoryje tak nravilis mne?"

11 "I ty znaješ zatšem ja javilsja k tebe / Dat tebe silu / Dat tebe vlast"

12 Danilan tapauksessa traagisuus on siinä, että se mitä hänen "täytyy" tehdä, on käydä väkivaltaista valtataistelua Pietarin alamaailman kans- 
sa - ja vähän muidenkin. Tällä tasolla taiteen tekijän suhde taiteensa kuluttajaan muuttuu ongelmalliseksi: miten suhtautua faniin, joka saa musiikista voimaa tappaakseen?

13 "Tšornyje ptitsy iz detskih glaz / Vykljujut tšornym kljuvom almaz"

14 "Vozmite mojo zoloto / I uletaite obratno / - Nam ne nužno tvojo zoloto / Zaržavelo tvojo zoloto

\section{Lähteet}

Beumers, Birgit (1999), To Moscow! To Moscow? The Russian Hero and the Loss of the Centre. - Russia on Reels. The Russian Idea in PostSoviet Cinema. Ed. Birgit Beumers. London \& New York: I. B. Tauris Publishers, 76-87.

Brown, Royal S. (1994), Overtones and Undertones. Reading Film Music. Berkeley: University of California Press.

Gorbman, Claudia (1987), Unheard Melodies. Narrative Film Music. Bloomington \& Indianapolis: Indiana University Press.

Gorbman, Claudia (2007), Auteur Music. - Beyond the Soundtrack. Representing Music in Cinema. Eds. Goldmark, Kramer \& Leppert. Berkeley: University of California Press, 149-162.

Gladilštšikov, Juri (1997), Sjužet dlja nebolšogo ubiistva. "Brat" - "Prijatel pokoinika". - Itogi, 10.6.1997. http://www.ctb.ru/content/view. jsp?id=662 (16.3.2010).

Gladilštšikov, Juri (2000), Odinotšnoje plavanije. "Brat-2" (slyšitsja "bratva"): naš otvet Džeimsu Bondu i protšemu "antisovetskomu kino". Itogi, 6.6.2000. http://www.ctb.ru/content/view. jsp?id=634 (16.3.2010).

Larsen, Susan (2003), National Identity, Cultural Authority, and the Post-Soviet Blockbuster: Nikita
/ I povsjudu na njom pjatna / [---] / Vozmite mojo tsarstvo / I vozmite moju koronu / - Nam ne nužno tvojo tsarstvo / Tvojo tsarstvo - jama v zemle syroi / I korona tvoja - iz kljona "

15 "Vozmite togda glaza moi / Štoby vas oni ne vidali / - Nam ne nužny glaza tvoi / My uže pobyvali v glazah tvoih / I vsjo što nam nužno vzjali”
Mikhalkov and Aleksei Balabanov. - Slavic Review 62:3, 491-511.

Lexmann, Juraj (2006), Theory of Film Music. Frankfurt am Main: Peter Lang.

Lotman, Juri \& Tsivjan, Juri (1994), Dialog $s$ ekranom. Tallinn: Aleksandra.

Margolit, E. (1998), Platš po pioneru, ili Nemetskoje slovo "Jablokitai". - Iskusstvo kino 2/1998, http://old.kinoart.ru/1998/2/9.html (16.3.2010).

Mantsov, I. (1998), Strogi junoša. - Iskusstvo kino 2, http://old.kinoart.ru/1998/2/10.html (16.3.2010).

Mera, Miguel (2005), Reap Just What You Sow: Trainspotting's Perfect Day. - Pop Fiction. The Song in Cinema. Eds. Steve Lannin \& Matthew Caley. Bristol \& Portland: Intellect Books, 85-98.

Österberg, Ira (2010), In Search of a Source. The Functions of Music in Aleksej Balabanov's Film "Brother". - Europe-Evropa: Cross-Cultural Dialogues between the West, Russia, and Southeastern Europe. Eds. Juhani Nuorluoto \& Maija Könönen. Uppsala: Acta Universitatis Upsaliensis, 151-166. 